\title{
Cell Models for the Study of Sex Steroid Hormone Neurobiology
}

Chang Su, Nataliya Rybalchenko, Derek A. Schreihofer, Meharvan Singh, Babak Abbassi and Rebecca L. Cunningham*

Department of Pharmacology and Neuroscience, University of North Texas Health Science Center at Fort Worth, Fort Worth, TX 76107 USA

\begin{abstract}
To date many aspects of neurons and glia biology remain elusive, due in part to the cellular and molecular complexity of the brain. In recent decades, cell models from different brain areas have been established and proven invaluable toward understanding this complexity. In the field of steroid hormone neurobiology, an important question is: what is the profile of steroid hormone receptor expression in these specific cell lines? Currently, a clear summary of such receptor profiling is lacking. For this reason, we summarized in this review the expression of estrogen, progesterone, and androgen receptors in several widely used cell lines (glial and neuronal) derived from the forebrain and midbrain, based on our own data and that from the literature. Such information will aid in the selection of specific cell lines used to test hypotheses related to the biology of estrogens, progestins, and/or androgens.
\end{abstract}

\section{Keywords: Androgen, Estrogen, Progesterone, GPR30, PGRMC1}

\section{Introduction}

\section{Sex steroid hormone receptors}

The investigation of sex steroid hormone-brain interactions can be traced back to 1849 , when A. A. Berthold transplanted testes into castrated roosters and observed the restoration of certain behavioral changes [1]. Sex steroid hormones (androgens, estrogens, and progestins) are known to mediate several biological effects, such as cell proliferation, differentiation, and homeostasis through their respective nuclear receptors. In addition to mediating transcriptional activities through their nuclear receptors, these hormones can mediate rapid activation through non-genomic signaling pathways [2].

The androgen receptor (AR) has two native ligands, testosterone and 5a-dihydrotesterone, which bind AR and activate transcription [3]. The AR is generally expressed as a single AR, and consists of $\mathrm{N}$-terminal regulatory domain, DNA-binding domain, a small hinge region, and ligand binding domain [4]. The $\mathrm{N}$-terminal regulatory domain mediates most of AR's transcriptional activity [5]. Two isoforms of AR $(\mathrm{A}, 87 \mathrm{kDa}$ and $\mathrm{B}, 110 \mathrm{kDa}$ ) have been identified in peripheral tissue, in which AR-A has a truncated N-terminus compared to full length AR-B [6]. In addition, a splice variant of AR, known as AR45, has been found in heart and skeletal muscle, but the biological significance of this splice variant is unknown [7]. Further, membrane-associated binding sites of AR have been found in several cell types, such as endothelial cells, prostate cancer cells, and breast cancer cells [8-10]. Indicative of non-genomic signaling, membrane-associated AR (mAR) is sensitive to g-protein coupled receptor antagonists but not AR antagonists [9]. Functionally, mAR has been associated with increased intracellular calcium [9]. As of yet, mAR has not been cloned. Distribution of AR mRNA containing cells has been identified in the forebrain, midbrain, brain stem, and spinal cord [11,12].

The estrogen receptor (ER) is expressed as two proteins, ERa and ER $\beta$, and produced from two different genes [13]. Binding of ER with estradiol, results in receptor dimerization and binding of ER to specific DNA sites in the gene promoter region, also known as the estrogen response element, to initiate transcription [14]. ERa generally has stronger transcriptional activation than ER $\beta$ whereas $\operatorname{ER} \beta$ can attenuate ERa transcriptional activity [15-17]. In addition to ER $\alpha$ and ER $\beta$, a g-protein coupled estrogen receptor, GPR30, has been shown to bind estrogen and mediate rapid non-genomic actions $[18,19]$ through g-protein activation [20]. Interestingly, expression of GPR30 can be upregulated by progestins [19]. Both ER $\alpha$ and ER $\beta$ have been observed in neurons and glia [21]. ER expression has been observed throughout the brain [22-25]. Although ER $\alpha$ and ER $\beta$ normally have overlapping expression patterns, ERa is generally more widely expressed in brain regions involved in reproductive function, while ER $\beta$ is widely distributed in regions involved in anxiety, depression, learning, and memory [26]. Increasing evidence suggests that ERa activation is anxiogenic [27] (Morgan et al., Lund et al.), while ER $\beta$ activation is anxiolytic and antidepressive [27-32].

Similar to estrogen receptors, the progesterone receptor (PR) has two isoforms, PR-A and PR-B [13]. However, unlike the estrogen receptor, $\mathrm{PR}-\mathrm{A}$ and $\mathrm{PR}-\mathrm{B}$ are produced from the alternate use of two promoters from the same gene [13]. PR-A, a truncated form of PR, is lacking the first 164 amino acids in the N-terminal domain [13]. Functionally, PR-B is a stronger activator than PR-A, whereas PR-A functions as a ligand-dependent repressor of other steroid hormone transcriptional activity, including PR-B, ER, and AR [33-35]. In addition to PR-A and PR-B, a novel membrane-associated g-protein coupled PR (mPR) has been cloned [36]. However, the biological significance of $\mathrm{mPR}$ mediating non-genomic actions of progesterone is currently unclear. Lastly, the progesterone receptor membrane component 1 (PGRMC1) is a member of the multi-protein binding complex regulated by progesterone, but its role in progesterone signaling is unknown [37-42]. This receptor has no homology similar to nuclear or membrane-associated steroid receptors [43]. Further, this receptor does not directly bind progesterone, but does activate P450 proteins involved in cholesterol synthesis and has been implicated in controlling membrane-associated signaling [44-46]. Distribution of PR has been localized to many brain regions, including the forebrain, midbrain, and brain stem [47-52].

*Corresponding author: Rebecca L. Cunningham, Ph.D, Department of Pharmacology and Neuroscience, University of North Texas Health Science Center at Fort Worth, 3500 Camp Bowie Blvd, Fort Worth, TX 76107, USA, Tel: 817-7355080; Fax: 817-735-0408; E-mail: Rebecca.Cunningham@unthsc.edu

Received September 06, 2011; Accepted October 11, 2011; Published October 15, 2011

Citation: Su C, Rybalchenko N, Schreihofer DA, Singh M, Abbassi B, et al. (2011) Cell Models for the Study of Sex Steroid Hormone Neurobiology. J Steroids Hormon Sci S2:003. doi:10.4172/2157-7536.S2-003

Copyright: (c) 2011 Su C, et al. This is an open-access article distributed unde the terms of the Creative Commons Attribution License, which permits unrestricted use, distribution, and reproduction in any medium, provided the original author and source are credited. 


\section{Clonal cell lines}

The field of steroid hormone neurobiology has benefited greatly from our growing knowledge of putative sex steroid hormone receptor sites and mapping of their distribution. Despite this progression, to date many aspects of the biology of neurons and glia remain elusive, mainly due to the cellular and molecular complexity of the brain. In addition, it remains technically challenging to perform in vivo studies on molecular mechanisms of hormonal regulation, receptor activation, intracellular signaling, and promoter/transcriptional regulation, with cells of different types and developmental origins. One way to reduce this complexity is to use primary neuronal and glial cultures. Nevertheless, non-transformed primary cultures may not always be ideal because of their short life span, and may represent a heterogeneous cell population. In order to overcome these issues, numerous labs have taken advantage of clonal cell lines, which are readily available, can go through multiple passages, and often represent a much more homogenous population of specific cell types with fewer uncontrolled variables than the in vivo situation.

From a historic perspective, the principles of brain cell culture began in the late $19^{\text {th }}$ century when the German embryologist Wilhelm Roux successfully removed the neural plate from chicken embryos and maintained it in warm saline solution for several days [53]. The groundwork laid down by pioneers, such as Sydney Ringer and Ross Harrison, was advanced significantly in the 1940s and 1950s [54]. The first immortalized cell line was developed by W. Earle and colleagues from mouse connective tissue in 1943 to bypass the limitation of cell senescence and death [55]. In 1984, Cepko developed retroviral shuttle vectors utilizing SV40 T-antigen-mediated replication, thus allowing researchers to retrovirally infect primary mammalian cells with an immortalizing oncogene and selectively propagate them [56]. These technologies paved the way for a completely new approach to scientific investigation using clonal cell lines as an in vitro model to study neurobiology.

In recent decades, cell models from different brain areas have been established and proven invaluable toward understanding the cellular biology of specific hormone-sensitive cells. Some commonly used cell lines include the GnRH GT1-7 neurons from hypothalamus, cholinergic CNh neurons from cerebral cortex, dopaminergic N27 neurons from midbrain, as well as glial C6 cells from glioma. Such cell lines represent distinct neuron and glia types, which express a specific array of receptors, neurotransmitters and neuropeptides. They retain, at least in part, the major functional features of the cells from which they originated, and make detailed cellular and molecular studies possible. Although cell lines lack the complexity of an intact brain and do not exhibit the same integrated network of cellular interconnections and signaling, results from cell lines have been shown to largely recapitulate the in vivo environment when studying effects such as hormonal regulation, gene expression, and receptor activation/signaling.

However, a clear summary of sex steroid hormone receptor profiling in cell lines is lacking. For this reason, we summarized, based on our own data and that from the literature, the expression of estrogen, progesterone, and androgen receptors in several widely used cell lines (glial and neuronal) derived from the forebrain, midbrain, and glia.

\section{Forebrain Cell Lines}

The forebrain, a component of the central cholinergic system, is a region of the brain associated with higher order processing, such as learning, memory, perceptual awareness, attention, language, consciousness, and emotional behavior [57-60]. Important structures located within the forebrain include the thalamus, hypothalamus, limbic system, basal ganglia, and cerebral cortex [61]. Increased interest in the function of the forebrain has occurred with increased knowledge of Alzheimer's disease, a form of progressive dementia affecting memory, thinking, language, perception, and emotional behavior [62]. Decreased cholinergic markers in the cerebral cortex, correlating with cortical pathology and cognitive impairment, have been found in patients diagnosed with Alzheimer's disease $[63,64]$. Interestingly, steroid hormones have been shown to have a neuroprotective quality in models of Alzheimer's disease [65-69].

\section{Cerebral cortical cell lines}

With increased knowledge of Alzheimer's disease, cerebral cortical cell lines have been utilized more. The most commonly used cortical cholinergic cell lines are derived from humans or mice. However, knowledge about steroid hormone receptors is scarce.

The HCN cell line is derived from cortical tissue removed from a patient undergoing hemispherectomy for intractable seizures, and it is positive for glutamate, somatostatin, gamma aminobutyric acid (GABA), and cholecystokinin [70]. Studies have shown that the HCN line is responsive to estrogen, in which estrogen protected cells from glutamate-induced toxicity and oxidative stress-induced cell death $[71,72]$. Characterization of this cell line for steroid hormone receptors has not been reported. However, partial steroid hormone characterization has been completed in another human cell line. The IMR-32 cell line is a human neuroblastoma cell line, derived from an abdominal mass, which mimics large projections of the cerebral cortex [73]. This line has both cholinergic and adrenergic properties [74-77]. This cell line does not express estrogen receptor alpha (ERa) [78].

Two commonly used cerebral cortical lines derived from mice are the CNh and the NG108-15 cell lines. The cholinergic CNh cell line expresses glutamate receptors $[79,80]$, but no studies have been reported on the effects of hormones or presence of steroid hormone receptors in this line. In contrast, the cholinergic NG108-15 hybridoma (mouse neuroblastoma x rat glioma C6) cell line [81] has been utilized in hormone assays studies. This cell expresses both ER $\alpha$ mRNA and ER $\beta$, protein, but does not express androgen receptors (AR) [82-84].

\section{Limbic region cell lines}

The limbic region is involved in emotional behavior, metabolic processes, activation of the autonomic nervous system, learning, and memory [57]. Structures that make up the limbic region include the hippocampus, olfactory cortex, septum, hippocampus, and other nuclei [57]. Steroid hormone characterization of cell lines derived from these structures has been conducted in our laboratories and other laboratories.

Three widely used hypothalamic cell lines include the GT1-7, mHypoE-46, and the GNV. The GT1-7 cell line is the most studied hypothalamic cell line to date. This gonadotropin-releasing hormone (GnRH) line was derived from a mouse hypothalamic SV40 transformed tumor [85]. This cell line mimics in vivo rhythmic pulsatile $\mathrm{GnRH}$ secretion and forms networks in culture [85]. We have found mRNA for ERa, ER $\beta$, and g-protein coupled estrogen receptor 1 (GPR30/ GPER) (Table 1), along with protein expression for AR [86]. Both ER $\beta$ mRNA and protein, and AR protein have consistently been shown to be present in GT1-7 cell lines [87-92]. Further, GT1-7 has been shown to bind androgens [93]. Other steroid receptors present in GT1-7 cells are the progesterone receptor $(\mathrm{PR})$ and the glucocorticoid receptor 
Citation: Su C, Rybalchenko N, Schreihofer DA, Singh M, Abbassi B, et al. (2011) Cell Models for the Study of Sex Steroid Hormone Neurobiology. J Steroids Hormon Sci S2:003. doi:10.4172/2157-7536.S2-003

(GR) [94,95]. However, the presence of ER $\alpha$ is unclear. Some studies report the presence of mRNA and protein for this receptor and binding of estrogen in GT1-7 cells [87-90,96], consistent with in vivo expression of ER $\alpha$ and ER $\beta$ receptors in GnRH neurons [97]. However, others have shown the absence of the ER receptor [94]. These differences in steroid hormone receptor profile may be partially mediated by the widely varied culturing conditions. Generally, DMEM or DMEM/ Ham's F-12 (1:1) media is used with $10 \%$ fetal bovine serum (FBS) [87-90,94] (Table 1), although one laboratory did use 5\% horse serum and 5\% fetal calf serum (FCS) instead of FBS [96]. Wide variations in supplements were also observed, consisting of sodium pyruvate, sodium bicarbonate, glucose, Glutamax, or L-glutamine added to the culture media [87-89,94,96].

Fewer studies have been reported on steroid hormone receptor profile in the mHypoE-46 and GNV cell lines. The mouse-derived mHypoE-46 cell line consists of NPY-expressing neurons [98]. The profile of steroid hormone receptors in this line consists of AR, GR, $\mathrm{ER} \alpha$, and ER $\beta$ mRNA [95]. Less is known about the GNV conditionally immortalized GnRH cell derived from an adult rat [99]. Only ERa and $\operatorname{ER} \beta$ receptors have been investigated and shown to be present at this time [95].

Two other GnRH cell lines have been used. The GN11 and NLT cell lines are derived from the same mouse olfactory tumor [100]. They both exhibit features of immature olfactory neurons, and have rhythmic pulsatile GnRH secretion [101]. However, the NLT cell line has a higher GnRH secretion than the GN11 line [100]. Our laboratory has found GPR30, ER $\alpha$, and ER $\beta$ mRNA in both cell lines (Table 1). Other laboratories have also shown ER $\alpha$ and ER $\beta$ mRNA and binding of radiolabeled estrogen to GN11 cells [87,94]. Additionally, the GN11 cell line contains PR mRNA, including membrane-associated PR (mPR) [94].

A widely used cholinergic cell line is the SN56 line that releases luteinizing hormone-releasing hormone (LHRH) [102]. This cell line is derived from a mouse septal neuroblastoma [103]. Our laboratory has found that the SN56 cells contain mRNA for GPR30, ERa, ER $\beta$,
$\mathrm{PR}, \mathrm{mPR}$, progesterone receptor membrane component 1 (PGRMC1), and AR (Table 1). Other laboratories have also found ER mRNA and protein expression, along with PR mRNA [104-106].

Two commonly used hippocampal-derived cell lines are the HT22 and the HN33 cells $[107,108]$. Our laboratory found mRNA for ERa, ER $\beta$, PGRMC1, and GPR30 and no mRNA PR, and AR in HT-22 cells. ERs in HT22 have been controversial. Several laboratories report the presence of $\mathrm{ERa}[106,109]$ and $\mathrm{ER} \beta$ [110], while other laboratories report the absence of ER $\alpha$ [111-115] and ER $\beta$ [109,111,115,116]. Interestingly, we have found that culturing conditions alter mRNA levels for ER $\beta$ in HT22 cells (Table 1). Generally, DMEM media is used, but serum supplementation and antibiotic usage can vary (i.e. FBS or FCS with either penicillin/streptomycin or gentamycin) [106,109116], indicating that culturing conditions may alter steroid hormone receptor expression. However, even less is reported in the literature about the steroid profile of the HN33 cell line. This cell line is a fusion of mouse hippocampal cells and N18TG2 neuroblastoma cells [108]. These cells display characteristics typical to hippocampal neurons, not neuroblastomas $[117,118]$. As of this date, our laboratory is the only one that has profiled the HN33 cells for steroid receptors. We have found GPR30, ERa, and ER $\beta$ steroid receptors (Table 1).

\section{Midbrain Cell Lines}

Major sources of catecholamines and catecholamine-releasing neurons are within the midbrain [119]. The midbrain is associated with motor control, cognition, emotion, and motivational control [120123]. Structures located with the midbrain include the substantia nigra, ventral tegmental area, and red nucleus [120]. Several pathological conditions are associated with the midbrain, such as Parkinson's disease, schizophrenia, and Tourette's syndrome [120]. Further, steroid hormones can modulate catecholaminergic neurons in the midbrain [124-126].

\section{Catecholamine cell lines}

The SH-SY5Y catecholamine cell line is derived from a human neuroblastoma and considered genetically female $[127,128]$. This cell

\begin{tabular}{|c|c|c|c|c|c|c|c|c|c|c|c|c|c|}
\hline Cell Line & $\begin{array}{l}\text { ? } \\
\alpha \\
\alpha\end{array}$ & 영 & 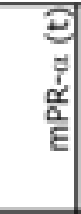 & 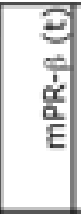 & 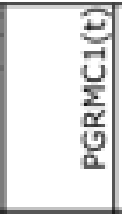 & 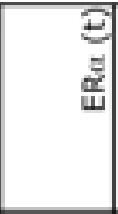 & ఏ & 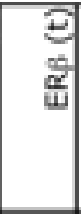 & 움 & 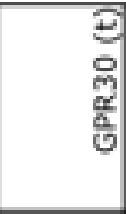 & $\begin{array}{l}\text { 의 } \\
\text { 얼 } \\
\text { 영 }\end{array}$ & 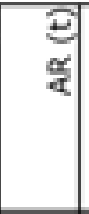 & ఏ \\
\hline GN11 & & & & & & ++ & & ++ & & ++ & & & \\
\hline GT1-7 & & & & & & + & & ++ & & ++ & & & ++ \\
\hline $\mathrm{HN} 33$ & & & & & & ++ & ++ & ++ & + & ++ & & & \\
\hline HT22 & 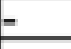 & & 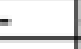 & - & +++ & +++ & & + & & + & & 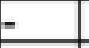 & \\
\hline HT22. & & & & & & ++ & +++ & ++ & + & + & & & \\
\hline NLT & & & & & & ++ & & ++ & & ++ & & & \\
\hline SN56 & + & & + & & +++ & ++ & & + & & +++ & & ++ & \\
\hline
\end{tabular}

Table 1: Steroid Hormone Receptor Profile for Forebrain Cell Lines.

$+=$ receptor level expression, $t=$ mRNA transcript, $\mathrm{p}=$ protein expression

This data was obtained from our laboratory and all cell passage numbers were less than 20 .

Culture condition for each cell type: GN-11 (DMEM $+10 \%$ fetal bovine serum (FBS) $+1 \%$ penicillin- streptomycin (PS), GTI-7 (DMEM + 10\% FBS + 1\% PS), HN33 (DMEM + 10\% FBS

$+1 \%$ PS), HT22 (DMEM + 10\% charcoal-stripped FBS + 20ug/ml gentamycin), HT22* (DMEM $+10 \%$ FBS + $1 \%$ PS), NLT (DMEM + 10\% FBS + 1\% PS), SN56 (DMEM + 10\% FBS + 1\% PS). 
Citation: Su C, Rybalchenko N, Schreihofer DA, Singh M, Abbassi B, et al. (2011) Cell Models for the Study of Sex Steroid Hormone Neurobiology. J Steroids Hormon Sci S2:003. doi:10.4172/2157-7536.S2-003

\begin{tabular}{|c|c|c|c|c|c|c|c|c|c|c|c|c|c|}
\hline Cell Line & $\begin{array}{l}= \\
\frac{\alpha}{\alpha}\end{array}$ & $\begin{array}{l}\text { 워 } \\
\frac{\alpha}{\alpha}\end{array}$ & $\begin{array}{l}\bar{\Xi} \\
\bar{j} \\
\frac{\alpha}{\alpha} \\
\text { E }\end{array}$ & $\begin{array}{l}\vec{O} \\
\overline{\hat{\alpha}} \\
\frac{\alpha}{\alpha} \\
\mathrm{E}\end{array}$ & 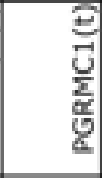 & 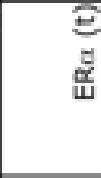 & 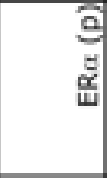 & 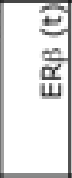 & $\begin{array}{l}\text { 의 } \\
\text { 햅 }\end{array}$ & $\begin{array}{l}3 \\
\text { 응 } \\
\frac{\alpha}{0} \\
\frac{0}{0}\end{array}$ & $\begin{array}{l}\text { 워 } \\
\circ \\
\bar{y} \\
\frac{\alpha}{0} \\
ن\end{array}$ & $\begin{array}{l}\Xi \\
\alpha \\
\alpha \\
\alpha\end{array}$ & $\begin{array}{l}\text { a } \\
\frac{\alpha}{4}\end{array}$ \\
\hline CAD & ++ & & ++ & - & ++ & & + & & & & & & \\
\hline N27 & - & & & & & + & + & + & & & & - & + \\
\hline N2A & & & & & & ++ & + & ++ & + & +++ & & & \\
\hline$P C=12$ & ++ & & +++ & ++ & $++t$ & - & & + & & & & 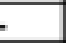 & \\
\hline SH-SYSY & - & & - & - & & - & & - & & & & & \\
\hline
\end{tabular}

Table 2: Steroid Hormone Receptor Profile for Midbrain Cell Lines.

$+=$ receptor level expression, $\mathrm{t}=$ mRNA transcript, $\mathrm{p}=$ protein expression

This data was obtained from our laboratory and all cell passage numbers were less than 20 , except PC-12. PC-12 cells were passaged between 80-90. Culture condition for each cell type: CAD (DMEM/F12 + 8\% FBS + 1\% PS), N27 (RPMI + 10\% FBS + 1\% PS), N2A (MEM + $10 \%$ FBS $+1 \%$ PS), PC-12 (RPMI + 5\% FBS $+10 \%$ heat inactivated horse serum $+1 \%$ PS), SH-SY5Y (DMEM/F12 + 10\% FBS + 1\% PS).

\begin{tabular}{|c|c|c|c|c|c|c|c|c|c|c|c|c|c|c|}
\hline Cell L & $\begin{array}{l}\Xi \\
\alpha \\
\alpha\end{array}$ & 产 & 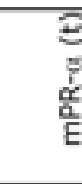 & है & 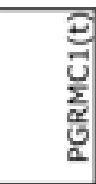 & \begin{tabular}{l}
3 \\
\multirow{3}{*}{}
\end{tabular} & $\begin{array}{l}\tilde{3} \\
\text { జ }\end{array}$ & 흡 & @ & 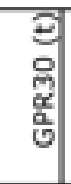 & 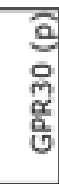 & & $\frac{2}{2}$ & ఏ్ర \\
\hline C6 & - & & ++ & ++ & +++ & - & & + & & & & - & t & \\
\hline T986 & + & & ++ & ++ & & - & & - & & & & & & \\
\hline
\end{tabular}

Table 3: Steroid Hormone Receptor Profile for Glial Cell Lines.

$+=$ receptor level expression, $t=$ mRNA transcript, $p=$ protein expression

This data was obtained from our laboratory and all cell passage numbers were less than 20 . Culture condition for each cell type: C6 (DMEM + 10\% FBS + 1\% Gentamicin), T98G (MEM + $10 \%$ FBS $+1 \%$ PS).

\begin{tabular}{|c|c|c|c|c|c|c|c|c|c|c|c|c|c|c|}
\hline Cell Line & $\begin{array}{l}\Xi \\
\alpha \\
\alpha\end{array}$ & $\begin{array}{l}\widehat{2} \\
\alpha \\
\alpha\end{array}$ & $\begin{array}{l}E \\
E \\
\frac{z}{z} \\
\dot{\alpha} \\
\frac{a}{E} \\
E\end{array}$ & $\begin{array}{l}\Xi \\
\frac{a}{\dot{\alpha}} \\
\frac{\alpha}{\alpha} \\
\frac{1}{E}\end{array}$ & 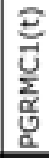 & $\begin{array}{l}\text { E } \\
\frac{\tilde{u}}{4} \\
\end{array}$ & $\begin{array}{l}\underline{\mathrm{a}} \\
\underline{z}\end{array}$ & $\begin{array}{l}\vec{E} \\
\bar{\alpha} \frac{}{\dot{\alpha}}\end{array}$ & $\begin{array}{l}\text { s } \\
\stackrel{a}{\underline{a}}\end{array}$ & $\begin{array}{l}\Xi \\
0 \\
0 \\
\alpha \\
0 \\
0\end{array}$ & $\begin{array}{l}\widehat{\mathrm{a}} \\
\circ \\
\mathrm{m} \\
\underline{0} \\
0\end{array}$ & $\begin{array}{l}\Xi \\
\frac{x}{4}\end{array}$ & $\frac{a}{a}$ & other \\
\hline $\mathrm{A} 172$ & & & & & & $=$ & & & & & & & + & \\
\hline C6 & - & - & + & 4 & + & $=1+$ & $-1+$ & $-1+$ & $-1+$ & & & - & + & \\
\hline CAD & + & & + & - & + & & + & & & & & & & \\
\hline Cath.a & & & & & & & - & & + & & & & & responsive to steroid hormones \\
\hline \multicolumn{15}{|l|}{ CNh } \\
\hline GN11 & + & & + & + & & \pm & + & \pm & & + & & & & \\
\hline GNV & & & & & & + & & + & & & & & & \\
\hline GT1-7 & + & + & + & & & $-1 \pm$ & + & \pm & + & + & & & \pm & \\
\hline $\mathrm{HCN}$ & & & & & & & & & & & & & & responsive to estrogen \\
\hline $\mathrm{HN} 33$ & & & & & & + & + & + & & 4 & & & & \\
\hline HT22 & - & & - & - & + & $-1 \pm$ & $-1+$ & $-1+$ & $-1+$ & + & & $-1+$ & & mERa, Erß splice variant \\
\hline IMR-32 & & & & & & - & & & & & & & & \\
\hline mHypoE-46 & & & & & & & + & & + & & & & + & \\
\hline N27 & - & & & & & + & + & + & & & & - & + & \\
\hline N2A & + & & & & & \pm & \pm & \pm & \pm & + & & + & & Erp splice variant \\
\hline NG108-15 & & & & & & + & & & + & & & - & & \\
\hline NLT & & & & & & + & & + & & + & & & & \\
\hline$P C-12$ & + & & + & + & + & - & & + & + & + & + & $-1+$ & + & \\
\hline SH-SY5Y & - & & $=$ & - & & $=$ & + & $=$ & + & & & $=$ & - & delta $7 E R a$ \\
\hline SN56 & + & & + & $=$ & + & \pm & + & $-1+$ & & + & & + & & $m E R \alpha$ \\
\hline T98G & + & & + & + & & $-1+$ & & $=$ & & & & + & + & \\
\hline U373MG & & & & & & + & & 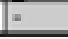 & & & & & & \\
\hline
\end{tabular}

Table 4: Steroid Hormone Receptor Profile for Reported Cell Lines.

Bold font indicates data only reported from our laboratory, while underlined foen indicates data from our laboratory that is consistent with previous reports. $t=m R N A$ transcript, $\mathrm{p}=$ protein expression 
line is dopaminergic, cholinergic, glutamatergic, and adenosinergic [128]. Our laboratory has been unable to find the presence of mRNA for ER or PR in this line (Table 2). Other laboratories have confirmed this reported absence of the AR [129]. However, protein expression of $\mathrm{ER} \alpha$ and ER $\beta$ in SH-SY5Y cells has been shown in other laboratories [130,131]. Culturing conditions may explain this discrepancy in steroid hormone receptor expression. Our laboratory used DMEM/ F12 media with 10\% FBS, whereas ER-positive cells were cultured in RPMI media with 10\% FBS and Glutamax supplementation [130,131]. Further, in ER-positive cells it is possible that the ERa is not functional, since the dominant negative form of ERa protein, delta7-ERa, is in higher proportion to full length ERa protein [131]. Loss of neuronal characteristics has been described with increased passages and this line is not recommended for use after twenty passages.

The rat mesencephalic-derived cell line, N27, is a catecholamine cell line [132]. This cell line produces dopamine, has tyrosine hydroxylase activity, and is positive for the dopamine transporter [132]. Our laboratory has found mRNA for ER $\alpha$ and ER $\beta$ but not AR or PR (Table 2). However, AR protein expression along with decreased cell viability and increased activation of the PKC $\delta$ pathway in response to androgens was observed, supporting the hypothesis that a putative membrane associated androgen receptor might mediate this responsiveness to androgens [86].

The PC-12 cell line is derived from a pheochromocytoma of the rat adrenal medulla [133], and is catecholaminergic with catecholamine synthesizing enzymes and monamine oxidase activity [134,135]. This cell line switches from a dividing neuroblastoma phenotype to a nondividing, neurite-bearing phenotype resembling mature sympathetic neurons when exposed to nerve growth factor (NGF) [133]. Our laboratory has found mRNA for PR, mPR, PGRMC1, ER $\beta$, and no mRNA for ERa and AR (Table 2). Other laboratories have found ER $\beta$ and GPR30 protein expression, but no ERa in PC-12 cells [136,137]. However, mRNA and protein expression for AR have been reported $[138,139]$. This difference in AR expression could be due to Glutamax supplementation, since the media and serum used are similar to what is used in our laboratory $[138,139]$ (Table 2).

The Cath.a cells are a catecholamine (dopamine and norepinephrine) synthesizing line that has a neuronal phenotype resembling locus coeruleus neurons [140]. These cells are derived from a brain tumor in a transgenic mouse with a SV40 T antigen under the transcriptional control of the rat tyrosine hydroxylase promoter [140]. Cath.a cells are responsive to estrogen, testosterone, and progesterone, as evidenced by altered CREB1 promoter activity [141]. Further, these cells express ER $\beta$ protein but not ERa [142].

The catecholaminergic CAD cell line is a variant of the Cath.a cells [140]. The CAD cells differ from Cath.a by loss of the immortalizing oncogene [143]. These cells exhibit characteristics similar to primary neurons [143]. Our laboratory has found the presence of mRNA for PR, mPR, and PGRMC1 (Table 2). However, recent reports show no PR protein expression in CAD cells [144]

\section{Neural Crest Cell Line}

The undifferentiated mouse neuroblastoma cell line N2A, also known as neuro2A, is a neural crest derived cell line [145]. This cell line expresses $\mathrm{TH}$ and can be differentiated into catecholaminergic cells $[146,147]$. Our laboratory has found mRNA for GPR30, ER $\alpha$, and ER $\beta$ (Table 2). This data is consistent with results in the literature showing that estrogen binds to receptors in $\mathrm{N} 2 \mathrm{~A}$ and the presence of mRNA and protein expression for both ER subtypes [115,148]. In addition, mRNA for AR and PR has been reported [148].

\section{Glial Cell Lines}

In the central nervous system, approximately $90 \%$ of the cells are glia [149]. Glia have been shown to have several functions, including serving as a transportation link between the bloodstream and neurons, uptake of neurotransmitters, synthesis and release of neurotrophic factors, immune regulation, and modulation of synaptic activity [150154]. Alzheimer's disease and Parkinson's disease have been associated with glial pathology $[155,156]$. Further, steroid hormones interactions with glia have been reported $[157,158]$.

A commonly used glial cell line is the C6 rat glioma astrocytoma [159]. Our laboratory has found the presence of mRNA for mPR, PGRMC1, and ER $\beta$, but not PR, AR, and ERa (Table 3). We have previously shown the presence of AR protein expression, indicating a putative membrane associated AR [160]. The presence of ER in C6 cells has been controversial. Some reports failed to detect ERs [161], whereas others note the presence of ER $\alpha$ and the absence of ER $\beta$ [162], or expression of both ERs [163]. These differences in steroid hormone receptor profile may partially be mediated by the widely varied culturing conditions, in which there is no consistency in media preference for C6 (i.e. DMEM, DMEM/F12, or RPMI) (Table 3).

Other glial cell lines include the human glioblastoma derived A172, T98G, and U373MG. Less information about the steroid receptor profiles of these lines are available. The A172 glial line is ER negative [164], but does express AR protein [165]. The T98G cells have mRNA for $E R \alpha$ and $\mathrm{mPR}$, but not $\mathrm{ER} \beta$, and protein expression for AR [162]. Further, our laboratory has found the presence of mRNA for PR but not ER in T98G glial cells (Table 3). Lastly, mRNA for ERa, not ER $\beta$, has been reported in the U373MG glial line [162].

\section{Conclusion}

While our knowledge from established central nervous system cell lines grows, concerns arise, since varied or even conflicting conclusions can be drawn from the same model. Varied observations might reflect differences in cell culture phenotype in different investigators' laboratories, which in turn may be due to culturing conditions, passage numbers, and so on. The formulation of cell culture media can also impact steroid hormone function [113,166]. For example, RPMI 1640 media contains glutathione but MEM, F12, and DMEM do not (see Invitrogen.com). The presence of glutathione in cell culture media has been shown to increase the potency of estrogens several hundred fold $[113,166]$. Therefore leading to an important question for investigators in the field of steroid hormone neurobiology: what is the profile of the sex steroid hormone receptor expression in the specific cell line being used? A thorough screening for receptors present in cells utilized by a specific lab is critical before choosing a model; yet, current literature lacks a clear summary, or at a minimum, a good guide of such profiling. For this reason, the present review is a progress report of these efforts from our own laboratory as well as others. This review provides an important insight of the utilization of clonal cell lines as our tools to investigate the mechanisms of steroid hormones in brain (Table 4).

\section{Acknowledgements}

We would like to thank Dr. David Schubert for the kind gift of HT-22 cells. This work was supported by the following grants: NIH F32 NS061417, AHA BGIA4180116, and UNTHSC Seed Grant to R.L.C. and NIH AG022550, AG027956, and an IIRG from Alzheimer's Association to M.S. 
Citation: Su C, Rybalchenko N, Schreihofer DA, Singh M, Abbassi B, et al. (2011) Cell Models for the Study of Sex Steroid Hormone Neurobiology. J Steroids Hormon Sci S2:003. doi:10.4172/2157-7536.S2-003

\section{References}

1. Berthold AA (1849) Transplatation des Hoden. Arch Anat Physiol Wiss Med 16: 42-46.

2. Simoncini T, Genazzani AR (2003) Non-genomic actions of sex steroid hormones. Eur J Endocrinol 148: 281-292.

3. Mangelsdorf DJ, Evans RM (1995) The RXR heterodimers and orphan receptors. Cell 83: 841-850.

4. Brinkmann AO, Faber PW, van Rooij HC, Kuiper GG, Ris C, et al. (1989) The human androgen receptor: domain structure, genomic organization and regulation of expression. J Steroid Biochem 34: 307-310

5. Simental JA, Sar M, Lane MV, French FS, Wilson EM (1991) Transcriptional activation and nuclear targeting signals of the human androgen receptor. J Bio Chem 266: 510-518.

6. Wilson CM, McPhaul MJ (1994) A and B forms of the androgen receptor are present in human genital skin fibroblasts. Proc Natl Acad Sci U S A 91: 12341238.

7. Ahrens-Fath I, Politz O, Geserick C, Haendler B (2005) Androgen recepto function is modulated by the tissue-specific AR45 variant. FEBS J 272: 74-84.

8. Figueroa-Valverde L, Luna H, Castillo-Henkel C, Muñoz-Garcia O, MoratoCartagena T, et al. (2002) Synthesis and evaluation of the cardiovascular effects of two, membrane impermeant, macromolecular complexes of dextrantestosterone. Steroids 67: 611-619.

9. Kampa M, Papakonstanti EA, Hatzoglou A, Stathopoulos EN, Stournaras C et al. (2002) The human prostate cancer cell line LNCaP bears functional membrane testosterone receptors that increase PSA secretion and modify actin cytoskeleton. FASEB J 16: 1429-1431.

10. Kampa M, Nifli AP, Charalampopoulos I, Alexaki VI, Theodoropoulos PA, et al. (2005) Opposing effects of estradiol- and testosterone-membrane binding sites on T47D breast cancer cell apoptosis. Exp Cell Res 307: 41-51.

11. Simerly RB, Chang C, Muramatsu M, Swanson LW (1990) Distribution of androgen and estrogen receptor mRNA-containing cells in the rat brain: an in situ hybridization study. J Comp Neurol 294: 76-95.

12. Yu WH, McGinnis MY (2001) Androgen receptors in cranial nerve motor nucle of male and female rats. J Neurobiol 46: 1-10.

13. Kuiper GG, Enmark E, Pelto-Huikko M, Nilsson S, Gustafsson JA (1996) Cloning of a novel receptor expressed in rat prostate and ovary. Proc Natl Acad Sci U S A 93: 5925-5930.

14. Tsai MJ, O'Malley BW (1994) Molecular mechanisms of action of steroid/ thyroid receptor superfamily members. Annu Rev Biochem 63: 451-486.

15. Cowley SM, Parker MG (1999) A comparison of transcriptional activation by ER alpha and ER beta. J Steroid Biochem Mol Biol 69: 165-175.

16. Hall JM, McDonnell DP (1999) The estrogen receptor beta-isoform (ERbeta) of the human estrogen receptor modulates ERalpha transcriptional activity and is a key regulator of the cellular response to estrogens and antiestrogens. Endocrinology 140: 5566-5578.

17. Mclnerney EM, Weis KE, Sun J, Mosselman S, Katzenellenbogen BS (1998) Transcription activation by the human estrogen receptor subtype beta (ER beta) studied with ER beta and ER alpha receptor chimeras. Endocrinology 139: 4513-4522

18. Revankar CM, Cimino DF, Sklar LA, Arterburn JB, Prossnitz ER (2005) A transmembrane intracellular estrogen receptor mediates rapid cell signaling. Science 307: 1625-1630

19. Thomas $P$, Pang $Y$, Filardo EJ, Dong J (2005) Identity of an estrogen membrane receptor coupled to a $\mathrm{G}$ protein in human breast cancer cells. Endocrinology 146: 624-632.

20. Maggiolini M, Vivacqua A, Fasanella G, Recchia AG, Sisci D, et al, (2004) The $\mathrm{G}$ protein-coupled receptor GPR30 mediates c-fos up-regulation by $17 \mathrm{beta}$ estradiol and phytoestrogens in breast cancer cells. J Biol Chem 279: 2700827016.

21. Donahue JE, Stopa EG, Chorsky RL, King JC, Schipper HM, et al. (2000) Cells containing immunoreactive estrogen receptor-alpha in the human basal forebrain. Brain Res 856: 142-151.

22. Osterlund MK, Grandien K, Keller E, Hurd YL (2000) The human brain has distinct regional expression patterns of estrogen receptor alpha mRNA isoforms derived from alternative promoters. J Neurochem 75: 1390-1397.

23. Shughrue PJ, Lane MV, Merchenthaler I (1997) Comparative distribution of estrogen receptor-alpha and -beta mRNA in the rat central nervous system. J Comp Neurol 388: 507-525.

24. González M, Cabrera-Socorro A, Pérez-García CG, Fraser JD, López FJ, et al (2007) Distribution patterns of estrogen receptor alpha and beta in the human cortex and hippocampus during development and adulthood. J Comp Neurol 503: 790-802.

25. Prewitt AK, Wilson ME (2007) Changes in estrogen receptor-alpha mRNA in the mouse cortex during development. Brain Res 1134: 62-69.

26. Mitra SW, Hoskin E, Yudkovitz J, Pear L, Wilkinson HA, et al. (2003) Immunolocalization of estrogen receptor beta in the mouse brain: comparison with estrogen receptor alpha. Endocrinology 144: 2055-2067.

27. Toufexis DJ, Myers KM, Bowser ME, Davis M (2007) Estrogen disrupts the inhibition of fear in female rats, possibly through the antagonistic effects of estrogen receptor alpha (ERalpha) and ERbeta. J Neurosci 27: 9729-9735.

28. Imwalle DB, Gustafsson JA, Rissman EF (2005) Lack of functional estrogen receptor beta influences anxiety behavior and serotonin content in female mice. Physiol Behav 84: 157-163

29. Krezel W, Dupont S, Krust A, Chambon P, Chapman PF (2001) Increased anxiety and synaptic plasticity in estrogen receptor beta -deficient mice. Proc Natl Acad Sci U S A 98: 12278-12282.

30. Donner N, Handa RJ (2009) Estrogen receptor beta regulates the expression of tryptophan-hydroxylase 2 mRNA within serotonergic neurons of the rat dorsa raphe nuclei. Neuroscience 163: 705-718.

31. Walf AA, Rhodes ME, Frye CA (2004) Antidepressant effects of ERbetaselective estrogen receptor modulators in the forced swim test. Pharmaco Biochem Behav 78: 523-529.

32. Hughes ZA, Liu F, Platt BJ, Dwyer JM, Pulicicchio CM, et al. (2008) WAY 200070 , a selective agonist of estrogen receptor beta as a potential nove anxiolytic/antidepressant agent. Neuropharmacology 54: 1136-1142.

33. Kastner P, Krust A, Turcotte B, Stropp U, Tora L, et al. (1990) Two distinct estrogen-regulated promoters generate transcripts encoding the two functionally different human progesterone receptor forms A and B. EMBO J 9: $1603-1614$

34. Giangrande PH, McDonnell DP (1999) The A and B isoforms of the human progesterone receptor: two functionally different transcription factors encoded by a single gene. Recent Prog Horm Res 54: 291-313.

35. Li X, O'Malley BW (2003) Unfolding the action of progesterone receptors. J Bio Chem 278: 39261-39264

36. Zhu Y, Rice CD, Pang Y, Pace M, Thomas P (2003) Cloning, expression and characterization of a membrane progestin receptor and evidence it is an intermediary in meiotic maturation of fish oocytes. Proc Natl Acad Sci U S A 100: $2231-2236$

37. Meyer C, Schmid R, Scriba PC, Wehling M (1996) Purification and partia sequencing of high-affinity progesterone-binding site(s) from porcine liver membranes. Eur J Biochem 239: 726-731.

38. Peluso JJ, Romak J, Liu X (2008) Progesterone receptor membrane component-1 (PGRMC1) is the mediator of progesterone's antiapoptotic action in spontaneously immortalized granulosa cells as revealed by PGRMC1 small interfering ribonucleic acid treatment and functional analysis of PGRMC1 mutations. Endocrinology 149: 534-543

39. Nilsson EE, Stanfield J, Skinner MK (2006) Interactions between progesterone and tumor necrosis factor-alpha in the regulation of primordial follicle assembly. Reproduction 132: 877-886.

40. Cai Z, Stocco C (2005) Expression and regulation of progestin membrane receptors in the rat corpus luteum. Endocrinology 146: 5522-5532.

41. Ace Cl, Okulicz WC (2004) Microarray profiling of progesterone-regulated endometrial genes during the rhesus monkey secretory phase. Reprod Biol Endocrinol 2: 54 .

42. Krebs CJ, Jarvis ED, Chan J, Lydon JP, Ogawa S, et al. (2000) A membraneassociated progesterone-binding protein, $25-\mathrm{Dx}$, is regulated by progesterone in brain regions involved in female reproductive behaviors. Proc Natl Acad Sci U S A 97: 12816-12821. 
43. Gerdes D, Wehling M, Leube B, Falkenstein E (1998) Cloning and tissue expression of two putative steroid membrane receptors. Biol Chem 379: $907-$ 911.

44. Min L, Takemori H, Nonaka Y, Katoh Y, Doi J, et al. (2004) Characterization of the adrenal-specific antigen IZA (inner zone antigen) and its role in the steroidogenesis. Mol Cell Endocrinol 215: 143-148.

45. Min L, Strushkevich NV, Harnastai IN, Iwamoto H, Gilep AA, et al. (2005) Molecular identification of adrenal inner zone antigen as a heme-binding protein. FEBS J 272: 5832-5843.

46. Hughes AL, Powell DW, Bard M, Eckstein J, Barbuch R, et al., (2007) Dap1/ PGRMC1 binds and regulates cytochrome P450 enzymes. Cell Metab 5: 143-

47. Hagihara K, Hirata S, Osada T, Hirai M, Kato J (1992) Distribution of cells containing progesterone receptor mRNA in the female rat di- and telencephalon: an in situ hybridization study. Brain Res Mol Brain Res 14: 239-249.

48. Guerra-Araiza C, Coyoy-Salgado A, Camacho-Arroyo I (2002) Sex differences in the regulation of progesterone receptor isoforms expression in the rat brain. Brain Res Bull 59: 105-109.

49. Guerra-Araiza C, Villamar-Cruz O, González-Arenas A, Chavira R, CamachoArroyo I (2003) Changes in progesterone receptor isoforms content in the rat brain during the oestrous cycle and after oestradiol and progesterone treatments. J Neuroendocrinol 15: 984-990.

50. Kato J, Hirata S, Nozawa A, Yamada-Mouri N (1994) Gene expression of progesterone receptor isoforms in the rat brain. Horm Behav 28: 454-463.

51. Kato J, Onouchi T (1983) Progestin receptors in female rat brain and hypophysis in the development from fetal to postnatal stages. Endocrinology 113: 29-36.

52. Kato J, Onouchi T, Takamatsu M (1984) Decreased progestin receptors in the cerebral cortex of hypothyroid postnatal rats. J Steroid Biochem 20: 817-819.

53. Hamburger V (1997) Wilhelm Roux: visionary with a blind spot. J Hist Biol 30: 229-238.

54. Alberts B et al., (2002) Molecular Biology of the Cell. $4^{\text {th }}$ ed. (2002) New York: Garland Science.

55. Earle WR (1943) Production of malignancy in vitro. IV. The mouse fibroblast cultures and changes seen in the living cells. J Natl Cancer Inst 4: 165-212.

56. Cepko CL, Roberts BE, Mulligan RC (1984) Construction and applications of a highly transmissible murine retrovirus shuttle vector. Cell 37:1053-1062.

57. Kandel ER, Siegelbaum SA (2000) The Anatomical Organization of the Central Nervous System, in Principles of Neural Science, E.R. Kandel, J.H. Schwartz, and T.M. Jessell, Editors. McGraw Hill: New York. 317-336.

58. Barrett LF, Quigley KS, Bliss-Moreau E, Aronson KR (2004) Interoceptive sensitivity and self-reports of emotional experience. J Pers Soc Psychol 87: 684-697.

59. Critchley HD, Wiens S, Rotshtein P, Ohman A, Dolan RJ (2004) Neural systems supporting interoceptive awareness. Nat Neurosci 7: 189-195

60. Dunnett SB, Everitt BJ, Robbins TW (1991) The basal forebrain-cortical cholinergic system: interpreting the functional consequences of excitotoxic lesions. Trends Neurosci 14: 494-501.

61. Braitenburg V, Schuz A (1991) Anatomy of the Cortex: Statistics and Geometry. New York: Springer-Verlag.

62. Querfurth HW, LaFerla FM (2010) Alzheimer's disease. N Engl J Med 362 329-344

63. Bowen DM, Smith CB, White P, Davison AN (1976) Neurotransmitter-related enzymes and indices of hypoxia in senile dementia and other abiotrophies. Brain 99: 459-496.

64. Perry EK, Tomlinson BE, Blessed G, Bergmann K, Gibson PH, et al. (1978) Correlation of cholinergic abnormalities with senile plaques and mental test scores in senile dementia. Br Med J 2: 1457-1459.

65. Pike CJ, Carroll JC, Rosario ER, Barron AM (2009) Protective actions of sex steroid hormones in Alzheimer's disease. Front Neuroendocrinol 30: 239-258.

66. Morinaga A, Ono K, Takasaki J, Ikeda T, Hirohata M, et al. (2011) Effects of sex hormones on Alzheimer's disease-associated beta-amyloid oligomer formation in vitro. Exp Neurol 228: 298-302.
67. Liu L, Zhao L, She H, Chen S, Wang JM, et al. (2010) Clinically relevant progestins regulate neurogenic and neuroprotective responses in vitro and in vivo. Endocrinology 151: 5782-5794.

68. Simpkins JW, Perez E, Wang X, Yang S, Wen Y, et al. (2009) The Potentia for Estrogens in Preventing Alzheimer's Disease. Ther Adv Neurol Disord 2 31-49.

69. Singh M, Sumien N, Kyser C, Simpkins JW (2008) Estrogens and progesterone as neuroprotectants: what animal models teach us. Front Biosci 13: 1083-1089.

70. Ronnett GV, Hester LD, Nye JS, Snyder SH (1994) Human cerebral cortical cell lines from patients with unilateral megalencephaly and Rasmussen's encephalitis. Neuroscience 63: 1081-1099.

71. Occhiuto F, Zangla G, Samperi S, Palumbo DR, Pino A, et al. (2008) The phytoestrogenic isoflavones from Trifolium pratense L. (Red clover) protects human cortical neurons from glutamate toxicity. Phytomedicine 15: 676-682.

72. Occhiuto F, Palumbo DR, Samperi S, Zangla G, Pino A, et al. (2009) The isoflavones mixture from Trifolium pratense L. protects HCN 1-A neurons from oxidative stress. Phytother Res 23: 192-196.

73. Rao RR, Kisaalita WS (2002) Biochemical and electrophysiological differentiation profile of a human neuroblastoma (IMR-32) cell line. In Vitro Cell Dev Biol Anim 38: 450-456.

74. Tumilowicz JJ, Nichols WW, Cholon JJ, Greene AE (1970) Definition of a continuous human cell line derived from neuroblastoma. Cancer Res 30: 2110 2118 .

75. Schlesinger HR, Gerson JM, Moorhead PS, Maguire H, Hummeler K (1976) Establishment and characterization of human neuroblastoma cell lines. Cancer Res 36: 3094-3100.

76. West GJ, Uki J, Herschman HR, Seeger RC (1977) Adrenergic, cholinergic, and inactive human neuroblastoma cell lines with the action-potential $\mathrm{Na}$ ionophore. Cancer Res 37: 1372-1376.

77. Neill D, Hughes D, Edwardson JA, Rima BK, Allsop D (1994) Human IMR-32 neuroblastoma cells as a model cell line in Alzheimer's disease research. $J$ Neurosci Res 39: 482-493.

78. Lee JM, Anderson PC, Padgitt JK, Hanson JM, Waters CM, et al. (2003) Nrf2, not the estrogen receptor, mediates catechol estrogen-induced activation of the antioxidant responsive element. Biochim Biophys Acta 1629: 92-101.

79. Allen DD, Martín J, Arriagada C, Cárdenas AM, Rapoport SI, et al. (2000) Impaired cholinergic function in cell lines derived from the cerebral cortex of normal and trisomy 16 mice. Eur J Neurosci 12: 3259-3264.

80. Cárdenas AM, Rodríguez MP, Cortés MP, Alvarez RM, Wei W, et al. (1999) Calcium signals in cell lines derived from the cerebral cortex of normal and trisomy 16 mice. Neuroreport 10: 363-369.

81. Machová E, Málková B, Lisá V, Nováková J, Dolezal V (2006) The increase of choline acetyltransferase activity by docosahexaenoic acid in NG108-15 cells grown in serum-free medium is independent of its effect on cell growth Neurochem Res 31: 1239-1246.

82. Aizawa S, Yamamuro $Y$ (2008) Estradiol regulates alternative splicing of estrogen receptor-alpha mRNA in differentiated NG108-15 neuronal cells. Life Sci 82: 692-698.

83. Nishio M, Kuroki Y, Watanabe $Y$ (2004) Subcellular localization of estrogen receptor beta in mouse hippocampus. Neurosci Lett 355: 109-112.

84. Nakajima H, Kimura F, Nakagawa T, Ikemoto T, Furutama D,et al. (1997) Effects of androgen receptor polyglutamine tract expansion on proliferation of NG108-15 cells. Neurosci Lett 222: 83-86

85. Mellon PL, Windle JJ, Goldsmith PC, Padula CA, Roberts JL, et al. (1990) Immortalization of hypothalamic $\mathrm{GnRH}$ neurons by genetically targeted tumorigenesis. Neuron 5: 1-10.

86. Cunningham RL, Giuffrida A, Roberts JL (2009) Androgens Induce Dopaminergic Neurotoxicity via Caspase-3-Dependent Activation of Protein Kinase Cd. Endocrinology 150: 5539-5548.

87. D'Orlando C, Guzzi F, Gravati M, Biella G, Toselli M, et al. (2008) Retinoic acidand phorbol ester-induced neuronal differentiation down-regulates caveolin expression in GnRH neurons. J Neurochem 104: 1577-1587.

88. Hu L, Gustofson RL, Feng H, Leung PK, Mores N, et al. (2008) Converse 
regulatory functions of estrogen receptor-alpha and -beta subtypes expressed in hypothalamic gonadotropin-releasing hormone neurons. Mol Endocrinol 22 2250-2259.

89. Roy D, Angelini NL, Belsham DD (1999) Estrogen directly respresses gonadotropin-releasing hormone $(\mathrm{GnRH})$ gene expression in estrogen receptor-alpha (ERalpha)- and ERbeta-expressing GT1-7 GnRH neurons. Endocrinology 140: 5045-5053.

90. Navarro CE, Abdul Saeed S, Murdock C, Martinez-Fuentes AJ, Arora KK, et al. (2003) Regulation of cyclic adenosine 3',5'-monophosphate signaling and pulsatile neurosecretion by $\mathrm{Gi}$-coupled plasma membrane estrogen receptors in immortalized gonadotropin-releasing hormone neurons. Mol Endocrinol 17 1792-804

91. Kalló I, Butler JA, Barkovics-Kalló M, Goubillon ML, Coen CW, et al. (2001) Oestrogen receptor beta-immunoreactivity in gonadotropin releasing hormoneexpressing neurones: regulation by oestrogen. J Neuroendocrinol 13: 741-748.

92. Belsham DD, Evangelou A, Roy D, Duc VL, Brown TJ (1998) Regulation of gonadotropin-releasing hormone $(\mathrm{GnRH})$ gene expression by 5alphadihydrotestosterone in GnRH-secreting GT1-7 hypothalamic neurons. Endocrinology 139: 1108-1114.

93. Poletti A, Melcangi RC, Negri-Cesi P, Maggi R, Martini L (1994) Steroid binding and metabolism in the luteinizing hormone-releasing hormone-producing neuronal cell line GT1-1. Endocrinology 135: 2623-2628.

94. Ng Y, Wolfe A, Novaira HJ, Radovick S (2009) Estrogen regulation of gene expression in $\mathrm{GnRH}$ neurons. Mol Cell Endocrinol 303: 25-33.

95. Mayer CM, Fick LJ, Gingerich S, Belsham DD (2009) Hypothalamic cell lines to investigate neuroendocrine control mechanisms. Front Neuroendocrinol 30: 405-423.

96. Shen ES, Meade EH, Pérez MC, Deecher DC, Negro-Vilar A, et al. (1998) Expression of functional estrogen receptors and galanin messenger ribonucleic acid in immortalized luteinizing hormone-releasing hormone neurons: estrogenic control of galanin gene expression. Endocrinology 139: 939-948.

97. Skynner MJ, Sim JA, Herbison AE (1999) Detection of estrogen receptor alpha and beta messenger ribonucleic acids in adult gonadotropin-releasing hormone neurons. Endocrinology 140: 5195-5201.

98. Belsham DD, Cai F, Cui H, Smukler SR, Salapatek AM, et al. (2004) Generation of a phenotypic array of hypothalamic neuronal cell models to study complex neuroendocrine disorders. Endocrinology 145: 393-400.

99. Salvi R, Castillo E, Voirol MJ, Glauser M, Rey JP, et al. (2006) Gonadotropinreleasing hormone-expressing neurons immortalized conditionally are activated by insulin: implication of the mitogen-activated protein kinase pathway. Endocrinology 147: 816-826.

100.Zhen S, Dunn IC, Wray S, Liu Y, Chappell PE, et al. (1997) An alternative gonadotropin-releasing hormone $(\mathrm{GnRH}) \mathrm{RNA}$ splicing product found in cultured GnRH neurons and mouse hypothalamus. J Biol Chem 272: 12620 12625.

101. Radovick S, Wray S, Lee E, Nicols DK, Nakayama Y, et al. (1991) Migratory arrest of gonadotropin-releasing hormone neurons in transgenic mice. Proc Natl Acad Sci U S A 88: 3402-3406.

102. Schreihofer DA (2005) Transcriptional regulation by phytoestrogens in neuronal cell lines. Mol Cell Endocrinol 231: 13-22.

103. Lee HJ, Hammond DN, Large TH, Wainer BH (1990) Immortalized young adult neurons from the septal region: generation and characterization. Brain Res Dev Brain Res 52: 219-228.

104. Martínez-Morales JR, López-Coviella I, Hernández-Jiménez JG, Reyes R Bello AR, et al. (2001) Sex steroids modulate luteinizing hormone-releasing hormone secretion in a cholinergic cell line from the basal forebrain. Neuroscience 103: 1025-1031.

105. Marin R, Guerra B, Alonso R (2001) The amount of estrogen receptor alpha increases after heat shock in a cholinergic cell line from the basal forebrain. Neuroscience 107: 447-454

106. Marin R, Ramírez CM, González M, Alonso R, Díaz M (2006) Alternative estrogen receptors homologous to classical receptor alpha in murine neural tissues. Neurosci Lett 395: 7-11.

107.Liu J, Li L, Suo WZ (2009) HT22 hippocampal neuronal cell line possesses functional cholinergic properties. Life Sci 84: 267-2671.
108. Min JY, Park MH, Park MK, Park KW, Lee NW, et al. (2006) Staurosporin induces neurite outgrowth through ROS generation in HN33 hippocampal cell lines. J Neural Transm 113: 1821-1826.

109. Deecher DC, Daoud P, Bhat RA, O'Connor LT (2005) Endogenously expressed estrogen receptors mediate neuroprotection in hippocampal cells (HT22). J Cell Biochem 95: 302-312.

110. Yang SH, Liu R, Perez EJ, Wen Y, Stevens SM, et al. (2004) Mitochondrial ocalization of estrogen receptor beta. Proc Natl Acad Sci U S A 101: 41304135 .

111. Manthey D, Heck S, Engert S, Behl C (2001) Estrogen induces a rapid secretion of amyloid beta precursor protein via the mitogen-activated protein kinase pathway. Eur J Biochem 268:. 4285-4291.

112. Behl C, Widmann M, Trapp T, Holsboer F (1995) 17-beta estradiol protects neurons from oxidative stress-induced cell death in vitro. Biochem Biophys Res Commun 216: 473-482.

113. Green PS, Gridley KE, Simpkins JW (1998) Nuclear estrogen receptorindependent neuroprotection by estratrienes: a novel interaction with glutathione. Neuroscience 84: 7-10.

114. Gursoy E, Cardounel A, Al-khlaiwi T, Al-drees A, Kalimi M (2002) Tamoxifen protects clonal mouse hippocampal (HT-22) cells against neurotoxins-induced cell death. Neurochem Int 40: 405-412.

115. Mendez P, Garcia-Segura LM (2006) Phosphatidylinositol 3-kinase and glycogen synthase kinase 3 regulate estrogen receptor-mediated transcription in neuronal cells. Endocrinology 147: 3027-3039.

116. Sheldahl LC, Shapiro RA, Bryant DN, Koerner IP, Dorsa DM (2008) Estrogen induces rapid translocation of estrogen receptor beta, but not estrogen receptor alpha, to the neuronal plasma membrane. Neuroscience 153: 751761.

117. Lee HJ, Hammond DN, Large TH, Roback JD, Sim JA, et al. (1990) Neurona properties and trophic activities of immortalized hippocampal cells from embryonic and young adult mice. J Neurosci 10: 1779-1787.

118. Watson DG, Wainer BH, Lenox RH (1994) Phorbol ester- and retinoic acidinduced regulation of the protein kinase $C$ substrate MARCKS in immortalized hippocampal cells. J Neurochem 63: 1666-1674.

119. Björklund A, Dunnett SB (2007) Dopamine neuron systems in the brain: an update. Trends Neurosci 30: 194-202.

120. Missale C, Nash SR, Robinson SW, Jaber M, Caron MG (1998) Dopamine receptors: from structure to function. Physiol Rev 78:189-225.

121. Jackson DM, Westlind-Danielsson A (1994) Dopamine receptors: molecula biology, biochemistry and behavioural aspects. Pharmacol Ther 64: 291-370.

122. Bromberg-Martin ES, Matsumoto M, Hikosaka O (2010) Dopamine in motivational control: rewarding, aversive, and alerting. Neuron 68: 815-834

123. Liss B, Roeper J (2008) Individual dopamine midbrain neurons: functional diversity and flexibility in health and disease. Brain Res Rev 58: 314-321.

124. Ragonese P, D’Amelio M, Savettieri G (2006) Implications for estrogens in Parkinson's disease: an epidemiological approach. Ann N Y Acad Sci 1089: 373-382.

125. Antzoulatos E, Jakowec MW, Petzinger GM, Wood R (2010) Sex differences in motor behavior in the MPTP mouse model of Parkinson's disease. Pharmaco Biochem Behav 95: 466-472.

126. Cunningham RL, Macheda T, Watts LT, Poteet E, Singh M, et al. (2011) Androgens exacerbate motor asymmetry in male rats with unilatera 6-hydroxydopamine lesion. Horm Behav: In Press.

127.Biedler JL, Helson L, Spengler BA (1973) Morphology and growth, tumorigenicity, and cytogenetics of human neuroblastoma cells in continuous culture. Cancer Res 33: 2643-2652.

128. Biedler JL, Roffler-Tarlov S, Schachner M, Freedman LS (1978) Multiple neurotransmitter synthesis by human neuroblastoma cell lines and clones. Cancer Res 38: 3751-3757.

129. Grierson AJ, Shaw CE, Miller CC (2001) Androgen induced cell death in SHSY5Y neuroblastoma cells expressing wild-type and spinal bulbar muscular atrophy mutant androgen receptors. Biochim Biophys Acta 1536: 13-20.

130. Wong J, Woon HG, Weickert CS (2011) Full length TrkB potentiates estrogen 
Citation: Su C, Rybalchenko N, Schreihofer DA, Singh M, Abbassi B, et al. (2011) Cell Models for the Study of Sex Steroid Hormone Neurobiology. J Steroids Hormon Sci S2:003. doi:10.4172/2157-7536.S2-003

Page 9 of 9

receptor alpha mediated transcription suggesting convergence of susceptibility pathways in schizophrenia. Mol Cell Neurosci 46: 67-78.

131.Wong J, Weickert CS (2009)Transcriptional interaction of an estrogen receptor splice variant and ErbB4 suggests convergence in gene susceptibility pathways in schizophrenia. J Biol Chem 284: 18824-18832.

132. Adams FS, La Rosa FG, Kumar S, Edwards-Prasad J, Kentroti S, et al. (1996) Characterization and transplantation of two neuronal cell lines with dopaminergic properties. Neurochem Res 21: 619-627.

133. Greene LA, Tischler AS (1976) Establishment of a noradrenergic clonal line of rat adrenal pheochromocytoma cells which respond to nerve growth factor. Proc Natl Acad Sci U S A 73: 2424-2428.

134. Mosharov EV, Staal RG, Bové J, Prou D, Hananiya A, et al. (2006) Alphasynuclein overexpression increases cytosolic catecholamine concentration. J Neurosci 26: 9304-9311.

135. Youdim MB, Heldman E, Pollard HB, Fleming P, McHugh E, et al. (1986) Contrasting monoamine oxidase activity and tyramine induced catecholamine release in PC12 and chromaffin cells. Neuroscience 19: 1311-1318.

136. Maharjan S, Serova L, Sabban EL (2005) Transcriptional regulation of tyrosine hydroxylase by estrogen: opposite effects with estrogen receptors alpha and beta and interactions with cyclic AMP. J Neurochem 93: 1502-1514.

137. Maharjan S, Serova LI, Sabban EL (2010) Membrane-initiated estradiol signaling increases tyrosine hydroxylase promoter activity with ER alpha in PC12 cells. J Neurochem 112: 42-55.

138. Gehlhaus M, Schmitt N, Volk B, Meyer RP (2007) Antiepileptic drugs affect neuronal androgen signaling via a cytochrome P450-dependent pathway. J Pharmacol Exp Ther 322: 550-559.

139. Meyer RP, Gehlhaus M, Schwab R, Bürck C, Knoth R, et al. (2009) Concordant up-regulation of cytochrome P450 Cyp3a11, testosterone oxidation and androgen receptor expression in mouse brain after xenobiotic treatment. $\mathrm{J}$ Neurochem 109: 670-681.

140.Suri C, Fung BP, Tischler AS, Chikaraishi DM (1993) Catecholaminergic cell lines from the brain and adrenal glands of tyrosine hydroxylase-SV40 T antigen transgenic mice. J Neurosci 13: 1280-1291.

141.Zubenko GS, Hughes HB (2010) Effects of the A(-115)G variant on CREB1 promoter activity in two brain cell lines: Interactions with gonadal steroids. Am J Med Genet B Neuropsychiatr Genet 153: 1365-1372.

142. Rincavage HL, McDonnell DP, Kuhn CM (2003) Expression of functional estrogen receptor beta in locus coeruleus-derived Cath.a cells. Endocrinology 144: 2829-2835

143. Qi Y, Wang JK, McMillian M, Chikaraishi DM (1997) Characterization of a CNS cell line, CAD, in which morphological differentiation is initiated by serum deprivation. J Neurosci 17: 1217-1225.

144. Jensik PJ, Arbogast LA (2011) Differential and Interactive Effects of LigandBound Progesterone Receptor A and B Isoforms on Tyrosine Hydroxylase Promoter Activity. J Neuroendocrinol 23: 915-925.

145. Evangelopoulos ME, Weis J, Krüttgen A (2005) Signalling pathways leading to neuroblastoma differentiation after serum withdrawal: HDL blocks neuroblastoma differentiation by inhibition of EGFR. Oncogene 24: 33093318.

146. Akahoshi E, Yoshimura S, Ishihara-Sugano M (2006) Over-expression of AhR (aryl hydrocarbon receptor) induces neural differentiation of Neuro2a cells: neurotoxicology study. Environ Health 5: 24.

147. Tremblay RG, Sikorska M, Sandhu JK, Lanthier P, Ribecco-Lutkiewicz M, et al. (2010) Differentiation of mouse Neuro 2A cells into dopamine neurons. J Neurosci Methods 18: 60-67.

148. Manthey D, Gamerdinger M, Behl C (2010) The selective beta1-adrenoceptor antagonist nebivolol is a potential oestrogen receptor agonist with neuroprotective abilities. Br J Pharmacol 159: 1264-1273.

149. Haydon PG (2001) Glia: listening and talking to the synapse. Nat Rev Neurosc 2: $185-193$.

150. Magistretti PJ, Pellerin L (1999) Astrocytes Couple Synaptic Activity to Glucose Utilization in the Brain. News Physiol Sci 14: 177-182.

151. Newman E, Reichenbach A (1996) The Muller cell: a functional element of the retina. Trends Neurosci, 19: 307-312.

152. Hüll M, Müksch B, Akundi RS, Waschbisch A, Hoozemans JJ, et al. (2006) Amyloid beta peptide (25-35) activates protein kinase C leading to cyclooxygenase-2 induction and prostaglandin E2 release in primary midbrain astrocytes. Neurochem Int 48: 663-672.

153. Henn FA, Hamberger A (1971) Glial cell function: uptake of transmitter substances. Proc Natl Acad Sci USA 68: 2686-2690.

154. Ullian EM, Sapperstein SK, Christopherson KS, Barres BA (2001) Control of synapse number by glia. Science 291: 657-661.

155. Siddiqui A, Mallajosyula JK, Rane A, Andersen JK (2011) Ability to delay neuropathological events associated with astrocytic MAO-B increase in Parkinsonian mouse model: implications for early intervention on disease progression. Neurobiol Dis 43: 527-532.

156. Diedrich JF, Minnigan H, Carp RI, Whitaker JN, Race R, et al. (1991) Neuropathological changes in scrapie and Alzheimer's disease are associated with increased expression of apolipoprotein $E$ and cathepsin $D$ in astrocytes. J Virol 65: 4759-4768.

157. Carroll RS, Zhang J, Dashner K, Sar M, Black PM (1995) Steroid hormone receptors in astrocytic neoplasms. Neurosurgery 37: 496-503.

158. Galbiati M, Saredi S, Melcangi RC (2003) Steroid hormones and growth factors act in an integrated manner at the levels of hypothalamic astrocytes: a role in the neuroendocrine control of reproduction. Ann N Y Acad Sci 1007 162-168.

159. Benda P, Lightbody J, Sato G, Levine L, Sweet W (1968) Differentiated rat glial cell strain in tissue culture. Science 161: 370-371.

160.Gatson JW, Kaur P, Singh M (2006) Dihydrotestosterone differentially modulates the mitogen-activated protein kinase and the phosphoinositide 3-kinase/Akt pathways through the nuclear and novel membrane androgen receptor in C6 cells. Endocrinology 147: 2028-2034

161. Kim YJ, Lee CJ, Lee U, Yoo YM (2005) Tamoxifen-induced cell death and expression of neurotrophic factors in cultured C6 glioma cells. J Neurooncol 71: $121-125$.

162. Yague JG, Lavaque E, Carretero J, Azcoitia I, Garcia-Segura LM (2004) Aromatase, the enzyme responsible for estrogen biosynthesis, is expressed by human and rat glioblastomas. Neurosci Lett 368: 279-284.

163. Sribnick EA, Ray SK, Banik NL (2006) Estrogen prevents glutamate-induced apoptosis in $\mathrm{C} 6$ glioma cells by a receptor-mediated mechanism. Neuroscience 137: $197-209$

164. Gandhari MK, Frazier CR, Hartenstein JS, Cloix JF, Bernier M, et al. (2010) Identification and characterization of estrogen receptor-related receptor alpha and gamma in human glioma and astrocytoma cells. Mol Cell Endocrinol 315 : 314-318.

165. Strakova N, Ehrmann J, Dzubak P, Bouchal J, Kolar Z (2004) The synthetic ligand of peroxisome proliferator-activated receptor-gamma ciglitazone affects human glioblastoma cell lines. J Pharmacol Exp Ther 309: 1239-1247.

166. Gridley KE, Green PS, Simpkins JW (1998) A novel, synergistic interaction between 17 beta-estradiol and glutathione in the protection of neurons agains beta-amyloid 25-35-induced toxicity in vitro. Mol Pharmacol 54: 874-880.
This article was originally published in a special issue, Androgen Receptors handled by Editor(s). Dr. Rebecca L Cunningham, University of North Texas Health Science Center, USA; Dr. Ze-hua Liu, Osaka City University, Japan 